\title{
Cashlet Theory: Discovering the Nature of Accounting
}

\author{
Ting-Kai Liu \\ Department of Operations Management \& Information Systems, College of Business, Northern Illinois University, DeKalb, USA \\ Email: tanklao@gmail.com
}

How to cite this paper: Liu, T.-K. (2017) Cashlet Theory: Discovering the Nature of Accounting. Open Journal of Accounting, 6, 11-32.

https://doi.org/10.4236/ojacct.2017.62002

Received: March 12, 2017

Accepted: April 25, 2017

Published: April 28, 2017

Copyright $\odot 2017$ by author and Scientific Research Publishing Inc. This work is licensed under the Creative Commons Attribution International License (CC BY 4.0).

http://creativecommons.org/licenses/by/4.0/

\begin{abstract}
Accounting is the "language of business", which records how our society works from the monetary aspect. Just like mathematics and science, accounting is one of the subjects that help people understand the world. However, accounting is not explained in a way that can be easily understood even for very basic concepts such as debit and credit. This article introduces a novel concept of cashlet into accounting area enlightened by chemistry. Cashlet is defined as a basic accounting unit with a value of negative one in the same way that electron is in chemistry. By comparing accounting transaction with chemical reaction, the author finds out that an accounting transaction is actually a process of transferring cashlets from one account to another just in the same way of a chemical redox reaction that transfers electrons from one chemical species to another. The account that gives cashlets is credited, while the account that takes cashlets is debited. Graphs are introduced to visualize the process. In cashlet theory, credit always means positive or plus (+), while debit always means negative or minus (-). Philosophically, when people give, they get credits; when people take, they get debits. The same idea is true in accounting. This article discovers that the nature of accounting is a process of moving cashlets between accounts and a process of recombining accounts, which simplifies the accounting concepts and helps people better understand the world through accounting.
\end{abstract}

\section{Keywords}

Cashlet Theory, Nature of Accounting, Graph Theory, Debit, Credit

\section{Introduction}

Accounting, recognized as the "language of business", counts the results of economic activities of an organization and conveys this information to stakeholders, investors, creditors, management, and regulators. The classic accounting was es- 
tablished in 1494 by Italian mathematician Luca Pacioli who was the first person to publish a work on the double-entry system of book-keeping [1]. In the double-entry accounting system, at least two accounting entries are required to record each financial transaction where every entry to an account requires a corresponding and opposite entry to a different account [2].

Double-entry bookkeeping is governed by the accounting equation:

$$
\text { Assets }=\text { Liabilities }+ \text { Equity. }
$$

At any time point, the equation should be true. Therefore, a change in one account must be matched with a change in another account. The terms debit and credit are used to record these opposite changes [2]. However, the usage of these terms in accounting is not the same with their everyday usage, sometimes even counter-intuitive, which makes accounting difficult for ordinary people to understand. Even worse, there is no consistency for an increase or a decrease of accounts by a debit or a credit post, which makes accounting even tougher. To break down these difficulties, I brought chemistry concepts to accounting.

Accounting equation is similar to chemical equation after several steps of transformation, and the knowledge of chemistry can be applied to accounting, which helps understand the nature of accounting from science perspective.

An accounting transaction is very similar to the chemical reaction named redox. Redox (short for reduction-oxidation reaction) is a chemical reaction where any such reaction involves both a reduction process and an opposite oxidation process simultaneously [3], which is similar to debit and credit posts of an accounting transaction. The electricity should be balanced to maintain a chemical equation in a similar way that the accounts should be balanced to maintain accounting equation.

In this article, I uncover the nature of accounting by comparing accounting equation with chemical equation and accounting transaction with chemical reaction. Using analogy, I introduce the concept of cashlet that is equivalent to electron in chemistry. I find out the nature of an accounting transaction is a process of transferring cashlets from one account to another, and the process can be visualized using graph theory. I discover that the nature of accounting is a process of moving cashlets and recombining accounts. Meanwhile, I introduce the concept of credit status, and simplify the terms "Debit" and "Credit", which makes accounting more accessible for ordinary people.

\section{Comparison of Accounting Equation and Chemical Equation}

Accounting equation is normally known as

$$
\text { Assets }=\text { Liabilities }+ \text { Equity or } A=L+E
$$

We can treat Liabilities + Equity as Liabilities in broader sense. Therefore the equation can be simplified as

$$
\text { Asset }=\text { Liabilities broader } \text { or } A=L b
$$

If we move A from left side of equation to right side, then the equation be- 
comes

$$
0=-A+L b
$$

Let's move all values and positive/negative sign to superscript, and give the left side a name-business. The equation becomes

$$
\text { Business }^{0}=A^{-}+L b^{+}
$$

which means business equal to assets and liabilities in broader sense.

Let's see a simple chemical equation of salt dissolution:

$$
\mathrm{NaCl}=\mathrm{Na}^{+}+\mathrm{Cl}^{-} \text {or } \text { Salt }^{0}=\mathrm{Na}^{+}+\mathrm{Cl}^{-}
$$

Here we can see the similarity of the new accounting equation and chemical equation. In chemical equation, we see $\mathrm{Cl}$ is negatively charged because it carries an electron. $\mathrm{Na}$ is positively charged because one of its electrons is depleted. The total electricity is 0 .

In order to apply chemistry to accounting, I introduce a novel concept of cashlet which is equivalent to electron in chemistry. Cashlet is a basic accounting unit the value of which is always negative one $(-1)$. The adjective form of cashlet is cashletic which is equivalent to electric. Cashlecity is equivalent to electricity. Chemical reaction is a process of moving electrons and recombination of atoms. The total electric charge of all atoms is always zero. Accounting transaction is the same thing: it's a process of moving cashlets and recombination of accounts. The total cashletic charge of all accounts is always zero.

In the new accounting equation (Business ${ }^{0}=A^{-}+L b^{+}$), we have the following properties:

1) Business is always neutral, which means its cashletic charge is always 0 .

2) The "+" sign between two accounts only means "AND", and between accounts there is only "AND" relationship (no minus relationship).

3) The calculation happens in the cashletic charge (or in the superscripts) of accounts.

4) The total cashletic charge of all accounts should be zero.

Based on the above prosperities, we can deduce lots of accounting equations. When a business is just set up, all accounts are neutral, which means all accounts have 0 cashletic charge. We can deduce the equation as following:

$$
\text { Business }=\text { Asset }+ \text { Liabilities in broader sense }(\mathrm{Lb})
$$

Since Lb = Liabilities + Equity, therefore:

$$
\text { Business }=\text { Asset }+ \text { Liabilities }+ \text { Equity }
$$

Since Equity $=$ Common Stock + Retained Earning , we have

Business $=$ Asset + Liabilities + Common Stock + Retained Earning

Since Retained Earning = Revenue + Expense + Dividend, and let's assume no dividend will be paid at early years of a business, we can deduce the following extended accounting equation which is called operational equation:

Business $=$ Asset + Liabilities + Common Stock + Revenue + Expense 
Abbreviated as

$$
B=A+L+\mathrm{CS}+\mathrm{Rev}+\operatorname{Exp}
$$

Note that between accounts there is always a + sign which means "AND". The actual calculations happen in the cashletic charge or in superscripts.

Let's have some examples and see how these equations work. Stockholders invest $\$ 10,000$ cash into a new company.

$$
B^{0}=A^{10,000-}+L^{0}+\mathrm{CS}^{10,000+}+\operatorname{Rev}^{0}+\operatorname{Exp}^{0}
$$

The company buys $\$ 2,000$ inventory by credit.

$$
B^{0}=A^{12,000-}+L^{2000+}+\mathrm{CS}^{10,000+}+\operatorname{Rev}^{0}+\operatorname{Exp}^{0}
$$

The company makes a sale of $\$ 1000$ by credit.

$$
B^{0}=A^{13,000-}+L^{2000+}+\operatorname{CS}^{10,000+}+\operatorname{Rev}^{1000+}+\operatorname{Exp}^{0}
$$

The company finds out that the inventory was reduced by $\$ 500$.

$$
B^{0}=A^{12,500-}+L^{2000+}+\mathrm{CS}^{10,000+}+\operatorname{Rev}^{1000+}+\operatorname{Exp}^{500-}
$$

We can see the equation is always balanced for each transaction. We can also consolidate accounts to get the information we need. For examples:

$$
\begin{gathered}
\operatorname{Rev}^{1000+}+\operatorname{Exp}^{500-}=\text { Income }^{500+} \\
\mathrm{CS}^{10,000+}+\operatorname{Rev}^{1000+}+\operatorname{Exp}^{500-}=\mathrm{E}^{10,500+} \\
B^{0}=A^{12,500-}+L^{2000+}+E^{10,500+}
\end{gathered}
$$

Using this approach we can extend the equation to all accounts at the lowest granule. We can consolidate proper accounts to get the information of interest. In this section, I introduce novel accounting concepts and novel accounting equation using analogy of chemical equation.

\section{Comparison of Accounting Transactions and Chemical Reaction}

Each accounting transaction involves at least two posts where one account is debited and the other is credited. These debit and credit should always happen together; they cannot occur independently. Accounting transaction is very similar to the chemical reaction of redox (short for reduction-oxidation reaction) where any such reaction involves both a reduction process and an opposite oxidation process simultaneously. These reduction and oxidation should always happen together; they cannot occur independently either. Here, I coin a term-crebitto abbreviate credit-debit transaction, which is equivalent to the term redox in chemistry.

Redox reactions involve the transfer of electrons between chemical species and the changes of oxidation state of chemical species. The chemical species from which the electrons are stripped is said to be oxidized, while the chemical species to which the electrons are added is said to be reduced. It can be explained in simple terms: 
Oxidation is the loss of electrons or an increase in oxidation state.

Reduction is the gain of electrons or a decrease in oxidation state.

The oxidation state, also known as the oxidation number, is an indicator of the degree of oxidation of a chemical species in a chemical compound. It can be positive, negative or zero. Similarly, I introduce the concept of credit state, which is an indicator of the degree of credit of an account in accounting. It can also be positive, negative or zero.

Using the analogy of redox reaction, we can describe accounting transaction as following: An accounting transaction involves the transfer of cashlets between accounts and the changes of credit state of accounts. The account from which cashlets are stripped is said to be credited, while the account to which the cashlets are added is said to be debited (or decredited). It can be explained in simple terms:

Credit is the loss of cashlets or an increase in credit state.

Debit is the gain of cashlets or a decrease in credit state.

To be more intuitive, it can be explained in this way:

When an account gives cashlets, it is credited.

When an account takes cashlets, it is debited.

When an account is credited, its credit state increases.

When an account is debited, its credit state decreases.

When an account's credit state increases, it must have been credited.

When an account's credit state decreases, it must have been debited.

The above statements are always true and there is no exceptions. Table 1 shows the comparison in details.

In chemistry, magnesium sulfide is formed by the reaction of sulfur (S) with magnesium $(\mathrm{Mg})$ where magnesium $(\mathrm{Mg})$ transfers two electrons to sulfur $(\mathrm{S})$. Conceptually, the reaction happens like:

Initial state: $\mathrm{Mg}^{0}+\mathrm{S}^{0}$

$\mathrm{Mg}$ is giving two electrons: $\mathrm{Mg}^{(2+)+(2-)}+\mathrm{S}^{0}$

$\mathrm{S}$ takes the two electrons: $\mathrm{Mg}^{2+}+\mathrm{S}^{2-}$

New compound is formed: $\mathrm{Mg}^{2+} \mathrm{S}^{2-}$ or $\mathrm{MgS}$

$\mathrm{Mg}$ is oxidized. It gives two electrons out and increases its oxidation state

Table 1. Comparison of accounting transactions and chemical reactions.

\begin{tabular}{cc}
\hline \multicolumn{1}{c}{ Accounting } & Chemistry \\
\hline Crebit or Credit-Debit transaction & Redox or Reduction-Oxidization reaction \\
Credit state & Oxidation state \\
$\begin{array}{c}\text { Credit is a process of giving cashlets, and } \\
\text { increase credit state }\end{array}$ & $\begin{array}{c}\text { Oxidation is a process of giving electrons, and } \\
\text { increase oxidation state }\end{array}$ \\
$\begin{array}{c}\text { Debit is a process of taking cashlets, and } \\
\text { decrease credit state }\end{array}$ & $\begin{array}{c}\text { Reduction is process of taking electrons, and } \\
\text { decrease oxidation state }\end{array}$ \\
\hline
\end{tabular}


from 0 to $2+. \mathrm{S}$ is reduced. It takes two electrons in and decreases its oxidation state from 0 to $2-$.

In accounting, when stockholders invest $\$ 10,000$ in cash for a new business, the transaction can be explained in accounting like:

Initial state: $\operatorname{Cash}^{0}+$ Common Stock $^{0}$

Common Stock is giving 10,000 cashlets: Cash $^{0}+$ Common Stock $^{(10,000+)+(10,000-)}$

Cash account takes the 10,000 cashlets: Cash $^{10,000-}+$ Common Stock $^{10,000+}$

Final state of the accounts: Cash $^{10,000-}+$ Common Stock $^{10,000+}$

Common stock is credited. It gives 10,000 cashlets out, and increases its credit state from 0 to $10,000+$. Cash account is debited. It takes 10,000 cashlets in, and decreases its credit state from 0 to $10,000-$.

Then the business purchases $\$ 2000$ equipment in cash, which can be explained like:

Initial state: Equipment ${ }^{0}+$ Cash $^{10,000-}$

Cash is giving cashlets: Equipment $^{0}+$ Cash $^{(10,000-)+(2000+)+2000-)}$

Equipment takes the cashlets: Equipment ${ }^{2000-}+\operatorname{Cash}^{(10,000-)+(2000+)}$

Final state: Equipment ${ }^{2000-}+$ Cash $^{8000-}$

Cash account is credited. It gives 2000 cashlets out, and increases its credit state from 10,000- to 8000-. Equipment is debited. It takes 2000 cashlets in, and decreases its credit status from 0 to $2000-$.

It's worth noting that the transfer of cashlets between accounts only changes the credit state of the involved accounts. It does not change the total cashletic charge of all accounts. Therefore, the total cashletic charge of all accounts involved should be the same before and after each transaction. For current example, the total charge of Equipment and Cash account is 10,000- before transaction. After transaction, the total charge of the two accounts is still 10,000-. Only the distribution of cashlets among accounts is changed.

\section{Expression of Accounting Transactions Using Graph Theory}

To visualize how cashlets move between accounts during transactions, I introduce graph theory to accounting. In computer sciences, graph theory is the study of graphs, which are mathematical structures used to model pairwise relations between objects [4]. Objects are termed as nodes that are usually expressed by circles or ellipses in graphs, while relations are termed edges that are normally lines or arrows connecting two nodes. Accounting transactions can be easily expressed using graph theory. Accounts are nodes, while transactions are edges. An edge always goes from one node to another denoting that cashlets moves from one account to another.

Let's look at an example. A new business gets investment of $\$ 10,000$ in cash by issuing common stocks (Event I). First, we identify two accounts (Common Stock and Cash) that are involved. They have zero balance at the beginning (Figure 1(a)). In second step, Common Stock account breaks down zero to $+\$ 10,000$ and $-\$ 10,000$ the sum of which is zero (Figure $1(b)$ ). In the third step, cashlets (with a charge of $-\$ 10,000$ ) move out of Common Stock account 
(Figure 1(c)). Finally, Cash account receives the cashlets of $-\$ 10,000$. Transaction is done (Figure 1(d)). For convenience of expression, we compress everything into one graph like Figure $1(\mathrm{e})$. The graph has the following properties:

1) At the beginning of time, each account (node) has zero balance.

2) For each transaction (edge), cashlets move from one account (node) to another account (node).

3) The account (node) that gives cashlets is credited, while the account (node) that receives cashlets is debited.

4) The credited amount is always denoted as positive, while the debited amount always negative.

5) If the negative and positive amounts are partitioned to two sets, the sum of one set is always the negative sum of the other.

Let's continue the example. Then the business buy $\$ 2000$ inventory using cash (II) and another $\$ 1000$ inventory by credit (III). It makes a sale of $\$ 3000$ by credit (IV) with the cost of goods sold at $\$ 1500$ (V). By the end of the month, it receives the $\$ 3000$ cash from its customer (VI), and pays the $\$ 1000$ cash to its vendor (VII). The whole business transactions can be expressed in graph like Figure $1(\mathrm{f})$.

Using graph, the movements of cashlets between accounts are clearly visualized, and the transactions become straightforward. The concept of debit and
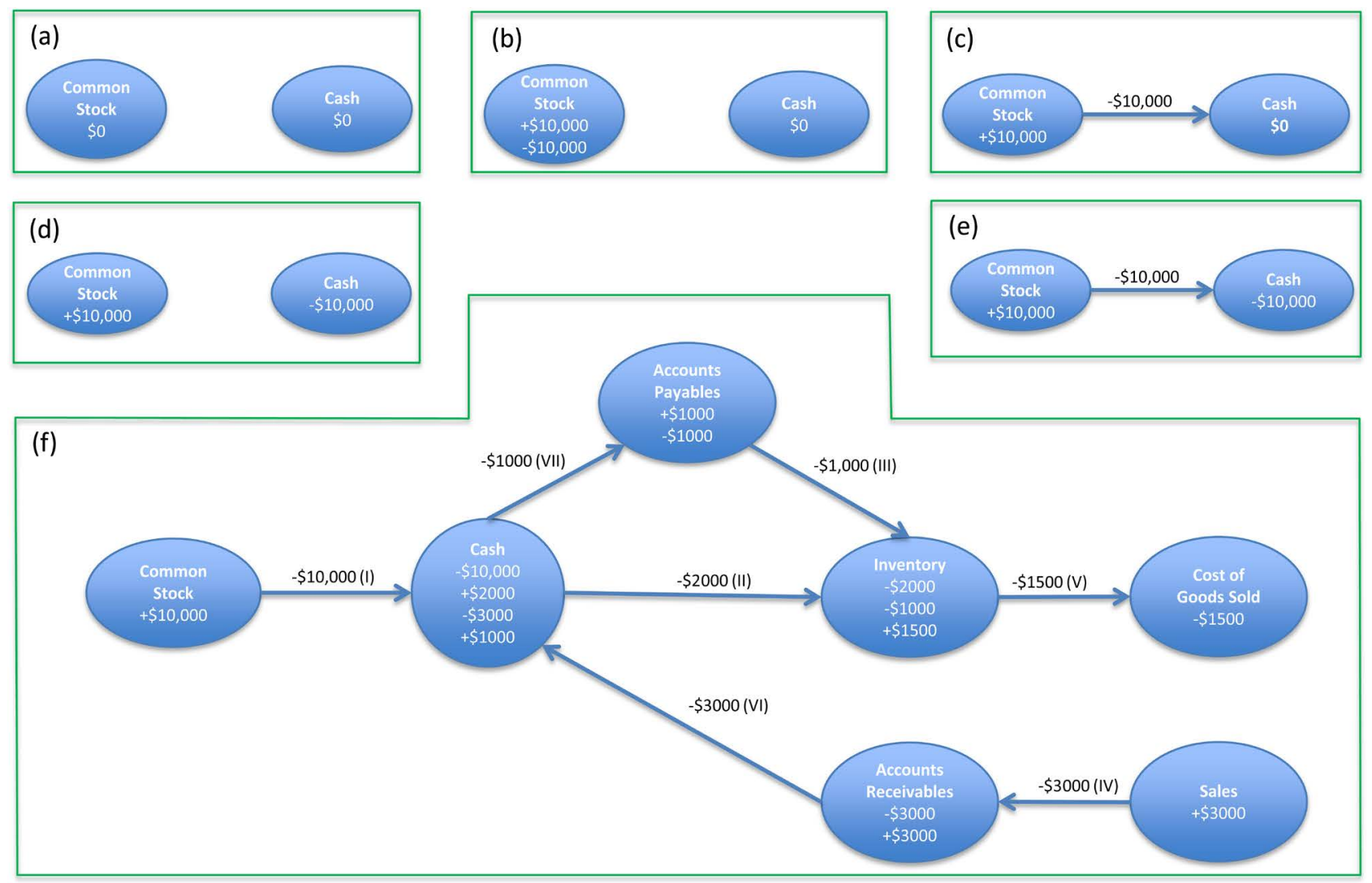

Figure 1. Expression of accounting transactions in graphs. (a) to (d) shows how cashlets are stripped and moved from one account to another. (e) compress the process of (a) to (d) into one graph. (f) shows how cashlets moves from accounts to accounts as business goes by. 
credit is also simplified: debit is nothing but a minus, while credit a plus.

\section{Accounts}

In cashlet theory, debit always decreases the credit state of accounts while credit always increases the credit state of accounts, no matter what types of accounts they are. However, business users may not be interested in credit state. Instead they are more interested in the absolute value of accounts. Therefore, we need to translate language of cashlet theory back to normal business language.

In cashlet theory, accounts can be categorized to three types: positive accounts, negative accounts and zero-balanced accounts. Positive accounts are with a positive credit state, while negative accounts are with negative credit state. Asset accounts and expense accounts are normally negative accounts, because they are cashlet carriers and cashlets are negative. Liability, equity, and revenue accounts are normally positive accounts, because they are cashlet donors. They donate negatively charged cashlets out leaving themselves positive.

Although a debit post to any account decreases the credit state of the account, the effect of absolute value of the account is different between positive accounts and negative accounts. For positive accounts, the absolute value decreases. However, for negative accounts, the absolute value increases, which means they're more negative in mathematics (Figure 2). Similarly, a credit post increases the credit

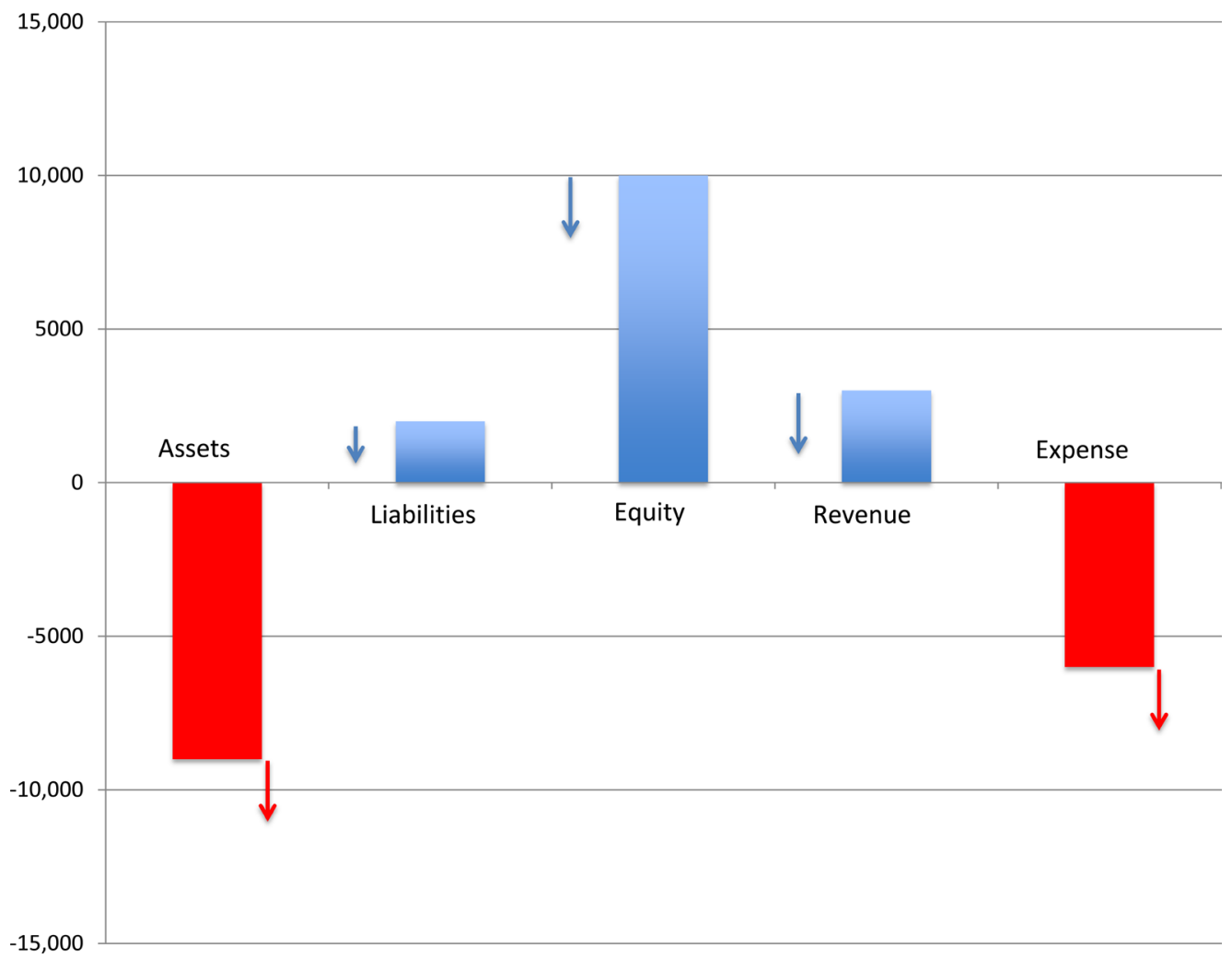

Figure 2. Effect of debit posts to different types of accounts. A debit post decreases credit state of accounts regardless of account types (all arrows go up). For positive accounts (in blue) the absolute value decreases. For negative accounts (in red), the absolute value increases, which means the accounts are more negative. 


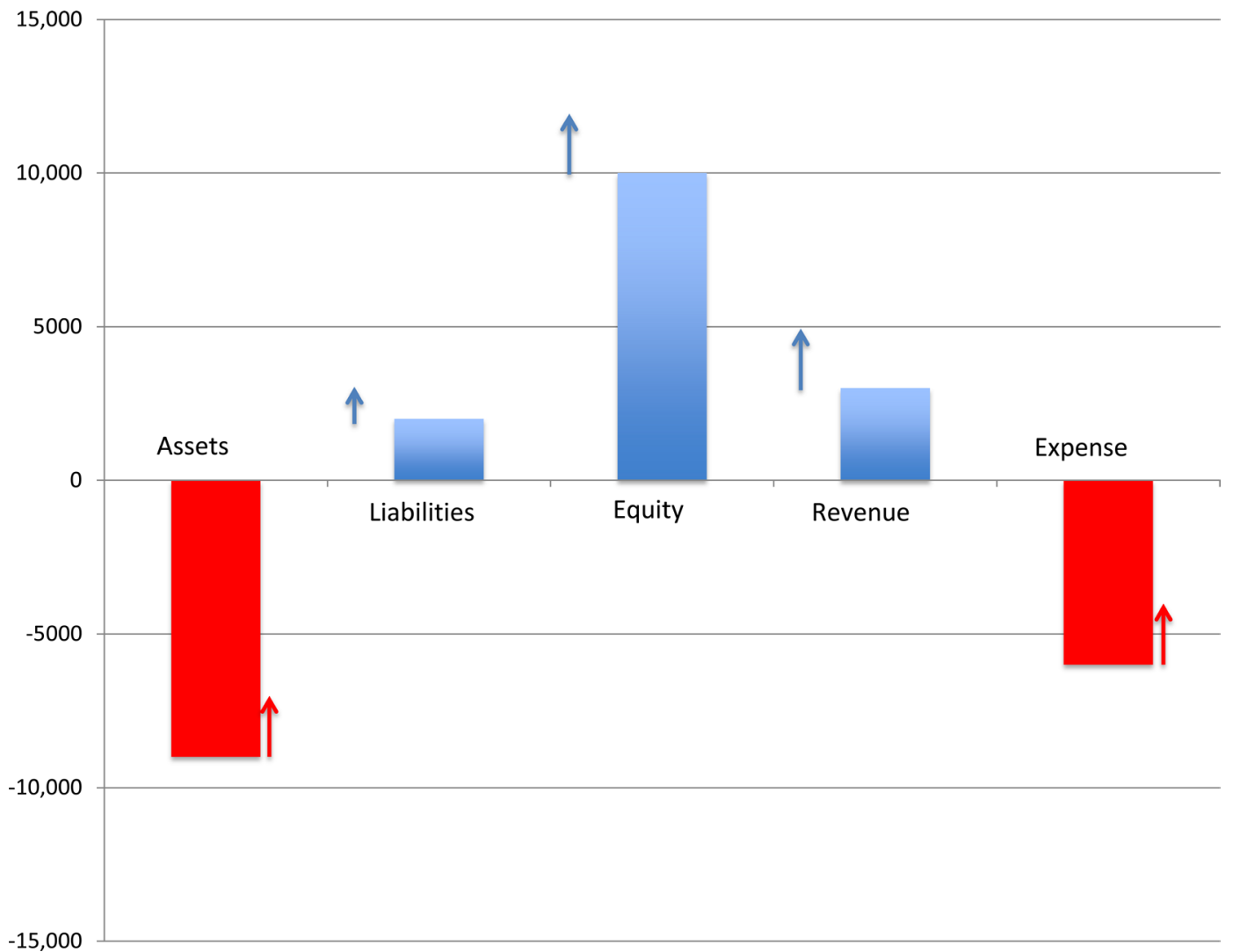

Figure 3. Effect of credit posts to different types of accounts. A credit post increases credit state of accounts regardless of account types (all arrows go down). For positive accounts (in blue) the absolute value increases. For negative accounts (in red), the absolute value decreases, which means the accounts are less negative.

state regardless of account types. For positive accounts the absolute value increases. For negative accounts, the absolute value decreases, which means the accounts are less negative (Figure 3 ).

\section{The Accounting Information System}

An accounting information system (AIS) is a system that a business uses to collect, store, manage, process, retrieve and report its financial data so that it can be used by internal and external users. Nowadays computers are involved from data collecting to final reporting in modern business. However, the classic concepts of debit and credit complicate data processing for computers. In cashlet theory, debit always means minus while credit always means plus, and the relationship between any accounts is always "AND", which makes it easy for computers to process data.

For data collection in classic accounting, transactions are initially recorded in chronological order in journals before they are posted to ledgers. For each transaction, the journal shows debit and credit effects on specific accounts. Therefore debit and credit are recorded in two separate columns. In cashlet theory, transactions are initially recorded in chronological order in a table that is then directly used as a source for any further data processing. Debit and credit are combined to one column called amount. Debit is always labeled as minus 
and credit always plus.

For data processing in classic accounting, one needs to remember the relationship of different accounts. For examples:

Book Value of Equipment $=$ Equipment - Accumulated Depreciation

$$
\text { Income }=\text { Revenue }- \text { Expense }
$$

In cashlet theory, the relationship between all accounts is AND or plus (+), because the calculation uses credit state, not the absolute value of accounts. The plus or minus information of each account is reflected in the credit state of the account. Therefore,

$$
\begin{gathered}
\text { Book Value of Equipment }=\text { Equipment }+ \text { Accumulated Depreciation } \\
\text { Income }=\text { Revenue }+ \text { Expense }
\end{gathered}
$$

In this way, data processing becomes easy, especially for computers. To calculate the balance of an account, just sum up all the entries of the account. To calculate the assets, sum up all asset accounts including contra-asset accounts. The balance sheet and income statements are nothing but summing up the accounts to levels that need to be reported.

\section{Case Study}

On January $2^{\text {nd }}, 2017$, Stockholders invest $\$ 10,000$ cash in a brand new company to be known as Laurens Corporation. On January $3^{\text {rd }}$, the company borrows cash of $\$ 5000$ by signing a 3-month, $12 \%, \$ 5000$ note payable. On January $4^{\text {th }}$, the company uses $\$ 1000$ cash to purchase equipment. On January $5^{\text {th }}$, the company purchase $\$ 2000$ inventory using cash, and buys another $\$ 1000$ inventory on credit. On January $15^{\text {th }}$, the company makes a sale of $\$ 3000$ on credit. On January $25^{\text {th }}$, it makes another sales of $\$ 5000$ on credit. On January $27^{\text {th }}$, the company pays $\$ 900$ in cash for office rental. On January $30^{\text {th }}$, the company receives $\$ 3000$ cash for the sale of January $15^{\text {th }}$. On the same day, it pays $\$ 4000$ cash for employee salary, and it also finds out that the inventory is reduced by $\$ 2500$. On the last of January, the company pays the $\$ 1000$ to its vendor for the inventory purchased on January $4^{\text {th }}$, and it also accrues $\$ 50$ interest expense for notes payable. All events are listed in Table 2.

Let's do a graphic analysis, an equation analysis and a debit-credit analysis before journalizing each transaction. The purpose of transaction analyses is first to identify the accounts and the types of accounts involved, and then to determine which account is debited and which is credited. The analysis of each transaction is illustrated in Figure 4.

We can visualize all transaction in one graph like Figure 5.

The journalized entries are showed in Table 3.

Using Pivot Table, we can easily calculate account balance for each account (Table 4).

We can also calculate the balance for each account category using Pivot Table (Table 5).

From Table 5, we can easily calculate Net Income by summing the credit state 
of Revenue and Expense.

Net Income $=$ Revenue + Expense $=(+\$ 8000)+(-\$ 7450)=\$ 550$.

We can also prepare the Income Statement based on the above two Pivot Tables (Table 6).

Retain Earning $=$ Net Income + Dividend. Since no Dividend was paid in January, Retain Earning is Net Income. We can prepare the balance sheet based on the above information (Table 7).

\section{Discussion}

In this work, I introduce two novel concepts-cashlet and credit state-to accounting enlightened by chemistry, and discover that the nature of accounting is a process of moving cashlets and recombination of accounts. I visualize accounting transactions using graphs, and simplify the concepts of debit and credit.

I make accounting more accessible for ordinary people. It's a common philosophy and is intuitive that if you give something you get credits. Similarly, we can deduce that if you take something you get debits. Accounting is actually in the same common sense: if an account gives cashlets, it gets credits. A simple mathematical approach to record the credits is to use a positive sign before the amount of cashlets the account gives. Similarly if an account takes cashlets, it gets debits. Mathematically, we put a negative sign before the amount it takes to record the debits. It's also easy to understand that when an account is credited, its credit state increases, and when debited, decreases. Up to now, everything is very intuitive. However, it becomes counter-intuitive that the cash account gets a

Table 2. List of all events of this case study.

\begin{tabular}{|c|c|c|}
\hline Event & Date & Description \\
\hline I & $1 / 2 / 2017$ & $\begin{array}{l}\text { Stockholders invest } \$ 10,000 \text { cash in a brand new company to be known as } \\
\text { Laurens Corporation. }\end{array}$ \\
\hline II & $1 / 3 / 2017$ & $\begin{array}{l}\text { Laurens borrows cash of } \$ 5000 \text { by signing a 3-month, } 12 \%, \$ 5000 \text { note } \\
\text { payable. }\end{array}$ \\
\hline III & $1 / 4 / 2017$ & Laurens uses $\$ 1000$ cash to purchase equipment. \\
\hline IV & $1 / 5 / 2017$ & Laurens uses $\$ 2000$ cash to purchase inventory. \\
\hline $\mathrm{V}$ & $1 / 5 / 2017$ & Laurens purchases $\$ 1000$ inventory on credit. \\
\hline VI & $1 / 15 / 2017$ & Laurens makes a sale of $\$ 3000$ on credit. \\
\hline VII & $1 / 25 / 2017$ & Laurens makes another sales of $\$ 5000$ on credit. \\
\hline VIII & $1 / 27 / 2017$ & Laurens pays $\$ 900$ for office rental in cash. \\
\hline IX & $1 / 30 / 2017$ & Laurens receives $\$ 3000$ cash for the sale on Jan 15 . \\
\hline $\mathrm{X}$ & $1 / 30 / 2017$ & Laurens pays employee salaries of $\$ 4000$ in cash. \\
\hline $\mathrm{XI}$ & $1 / 30 / 2017$ & Laurens finds out that inventory is reduced by $\$ 2500$. \\
\hline XII & $1 / 31 / 2017$ & Laurens pays the $\$ 1000$ to vendor for inventory purchased on Jan 5 \\
\hline XIII & $1 / 31 / 2017$ & Laurens accrues $\$ 50$ interest expense for the notes payable \\
\hline
\end{tabular}


Event I

Graphic

Analysis

Equation

Analysis

Debit-Credit Analysis

Journal Entry

Event II

Graphic Analysis

Equation Analysis

Debit-Credit Analysis

Journal Entry

Event III

Graphic Analysis

Equation Analysis

Debit-Credit Analysis

Journal Entry
On Jan 2, 2017, stockholders invest $\$ 10,000$ cash in a brand new company to be known as Laurens Corporation.

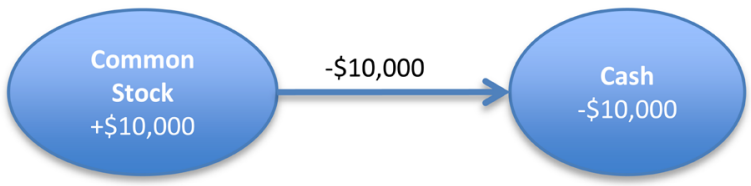

Business = Assets + Liabilities + Common Stock + Revenue + Expense

$0=\frac{\text { Cash }}{-\$ 10,000}+\frac{\text { Common Stock }}{+\$ 10,000}$

Common Stock is credited, because it gives cashlets.

Cash account is debited, because it receives cashlets

\begin{tabular}{|l|l|l|l|}
\hline Date & Account & Amount & Notes \\
\hline Jan 2, 2017 & Common Stock & $+\$ 10,000$ & \\
\hline Jan 2, 2017 & Cash & $-\$ 10,000$ & From Common Stock \\
\hline
\end{tabular}

On Jan 3, 2017, Laurens borrows cash of $\$ 5000$ by signing a 3-month, $12 \%, \$ 5000$ note payable.

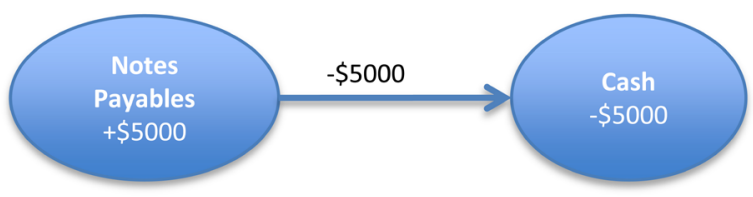

$$
\begin{aligned}
\text { Business } & =\text { Assets } \\
0 & =\frac{\text { Cash }}{-\$ 5000}+\frac{\text { Liabilities }}{+}+\frac{\text { Notes Payable }}{+\$ 5000}
\end{aligned}
$$

- Notes Payable is credited, because it gives cashlets.

Cash account is debited, because it receives cashlets

\begin{tabular}{|l|l|l|l|}
\hline \multicolumn{1}{|l|}{ Date } & Account & Amount & Notes \\
\hline Jan 3, 2017 & Notes Payable & $+\$ 5000$ & 3-month, 12\% note \\
\hline Jan 3, 2017 & Cash & $-\$ 5000$ & \\
\hline
\end{tabular}

On Jan 4, Laurens uses $\$ 1000$ cash to purchase equipment.

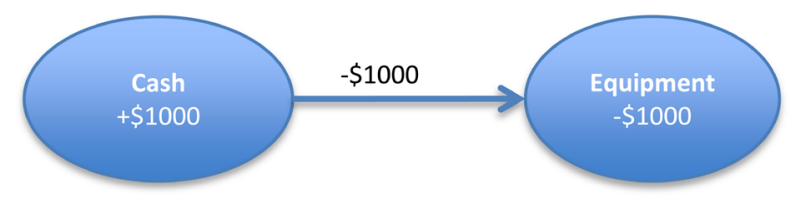

Business Assets + Liabilities + Common Stock + Revenue + Expense $0=\frac{\text { Cash }}{+\$ 1000}+\frac{\text { Equipment }}{-\$ 1000}$

Cash is credited, because it gives cashlets.

Equipment is debited, because it receives cashlets

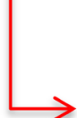

\begin{tabular}{|l|l|}
\hline Date & Account \\
\hline Jan 4, 2017 & Cash \\
\hline Jan 4, 2017 & Equipment \\
\hline
\end{tabular}

Amount

Notes

$+\$ 1000$

$-\$ 1000$ 
Event IV

Graphic Analysis

Equation Analysis

Debit-Credit Analysis

Journal Entry

Event V

Graphic Analysis

Equation Analysis

Debit-Credit Analysis

Journal Entry

Graphic
Analysis

Equation Analysis

Debit-Credit Analysis

Journal Entry
On Jan 5, Laurens uses $\$ 2000$ cash to purchase inventory.

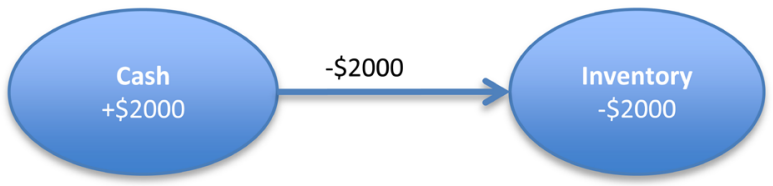

$$
\begin{aligned}
\text { Business } & =\frac{\text { Assets }}{0}=\frac{\text { Cash }}{+\$ 2000}+\frac{\text { Inventory }}{-\$ 2000}
\end{aligned}
$$

- Cash is credited, because it gives cashlets.

Inventory is debited, because it receives cashlets

\begin{tabular}{|l|l|l|l|}
\hline Date & Account & Amount & Notes \\
\hline Jan 5, 2017 & Cash & $+\$ 2000$ & \\
\hline Jan 5, 2017 & Inventory & $-\$ 2000$ & \\
\hline
\end{tabular}

On Jan 5, Laurens purchases \$1000 inventory on credit.

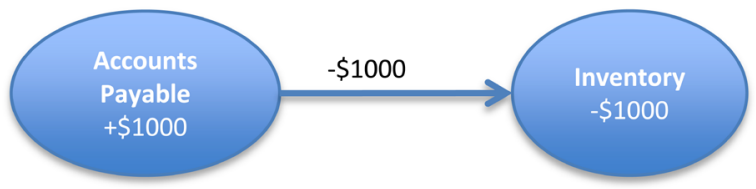

$$
\begin{array}{cl}
\text { Business } & =\text { Assets } \\
0 & =\frac{\text { Inventory }}{-\$ 1000}+\frac{\text { Liabilities }+ \text { Common Stock + Revenue + Expense }}{+\$ 1000}
\end{array}
$$

- Accounts Payable is credited, because it gives cashlets.

Cash account is debited, because it receives cashlets

\begin{tabular}{|l|l|l|l|}
\hline \multicolumn{1}{|l|}{ Date } & Account & Amount & Notes \\
\hline Jan 5, 2017 & Accounts Payable & $+\$ 1000$ & \\
\hline Jan 5, 2017 & Cash & $-\$ 1000$ & \\
\hline
\end{tabular}

On Jan 15, 2017, Laurens makes a sale of $\$ 3000$ on credit.

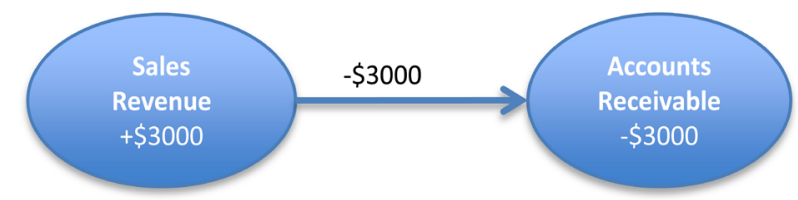

$$
\begin{array}{cccc}
\text { Business } & =\text { Assets } & + \text { Liabilities }+ \text { Common Stock }+ \text { Revenue }+ \text { Expense } \\
0 & =\frac{\text { Accounts Rec. }}{-\$ 3000} & + & \frac{\text { Sales Revenue }}{+\$ 3000}
\end{array}
$$

- Sales Revenue is credited, because it gives cashlets.

Accounts Receivable is debited, because it receives cashlets

\begin{tabular}{|l|l|l|l|}
\hline \multicolumn{1}{|l|}{ Date } & Account & Amount & Notes \\
\hline & Jan 15,2017 & Sales Revenue & $+\$ 3000$ \\
\hline Jan 15,2017 & Accounts Receivable & $-\$ 3000$ & \\
\hline
\end{tabular}


Event VII

Graphic

Analysis

Equation

Analysis

Debit-Credit

Analysis

Journal

Entry

Event VIII

Graphic

Analysis

Equation

Analysis

Debit-Credit

Analysis

Journal

Entry

Event IX

Graphic

Analysis

Equation

Analysis

Debit-Credit

Analysis

Journal

Entry

On Jan 25,2017 , Laurens makes another sales of $\$ 5000$ on credit.

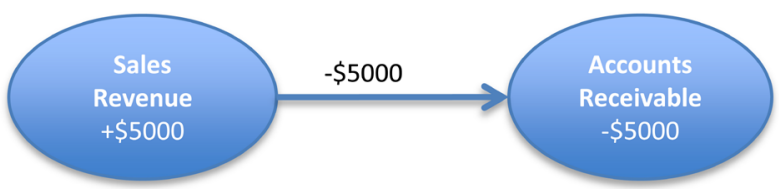

$$
\begin{array}{cccc}
\text { Business } & =\text { Assets } & + \text { Liabilities } & + \text { Common Stock }+ \text { Revenue }+ \text { Expense } \\
0 & =\frac{\text { Accounts Rec. }}{-\$ 5000} & + & \frac{\text { Sales Revenue }}{+\$ 5000}
\end{array}
$$

- Sales Revenue is credited, because it gives cashlets.

Accounts Receivable is debited, because it receives cashlets

\begin{tabular}{|l|l|l|l|}
\hline Date & Account & Amount & Notes \\
\hline Jan 25, 2017 & Sales Revenue & $+\$ 5000$ & \\
\hline Jan 25, 2017 & Accounts Receivable & $-\$ 5000$ & \\
\hline
\end{tabular}

On Jan 27,2017 , Laurens pays $\$ 900$ for office rental in cash.

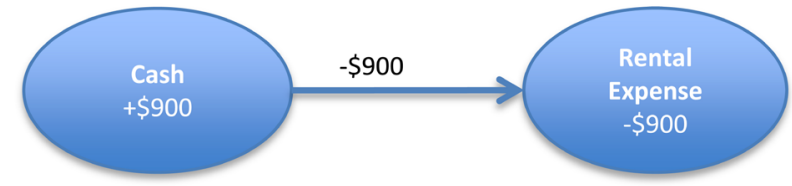

$$
\begin{array}{rlrl}
\text { Business } & = & \text { Assets }+ \text { Liabilities }+ \text { Common Stock + Revenue }+ \text { Expense } \\
0 & =\frac{\text { Cash }}{+\$ 900} & + & \frac{\text { Rental Expense }}{-\$ 900}
\end{array}
$$

- Cash is credited, because it gives cashlets.

Rental Expense is debited, because it receives cashlets

\begin{tabular}{|l|l|l|l|}
\hline Date & Account & Amount & Notes \\
\hline Jan 27, 2017 & Cash & $+\$ 900$ & \\
\hline Jan 27, 2017 & Rental Expense & $-\$ 900$ & \\
\hline
\end{tabular}

On Jan 30, Laurens receives $\$ 3000$ cash for the sale on Jan 15.

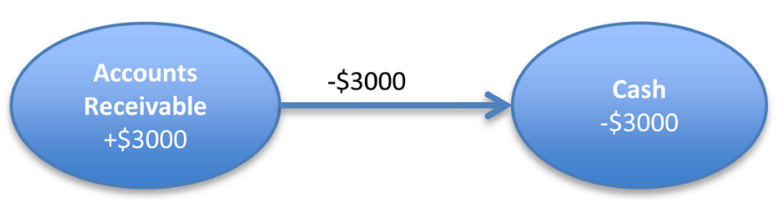

$$
\begin{aligned}
\text { Business } & =\frac{\text { Assets }+ \text { Liabilities + Common Stock + Revenue + Expense }}{0}=\frac{\text { Cash }}{-\$ 3000}+\frac{\text { Acct. Rec. }}{+\$ 3000}
\end{aligned}
$$

- Accounts Receivable is credited, because it gives cashlets.

Cash account is debited, because it receives cashlets

\begin{tabular}{|l|l|l|l|}
\hline Date & Account & Amount & Notes \\
\hline Jan 30,2017 & Accounts Receivable & $+\$ 3000$ & \\
\hline Jan 30,2017 & Cash & $-\$ 3000$ & \\
\hline
\end{tabular}


Event X

Graphic

Analysis

Equation

Analysis

Debit-Credit

Analysis

Journal

Entry

Analysis

Equation

Analysis

Debit-Credit

Analysis

Journal

Entry

Event XI

Graphic Analysis

Equation

Analysis

Debit-Credit

Analysis

Journal

Entry
On Jan 30, Laurens pays employee salaries of $\$ 4000$ in cash.

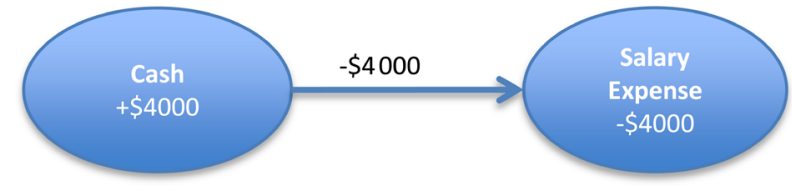
Business $=$ Assets + Liabilities + Common Stock + Revenue + Expense
$0=\frac{\text { Cash }}{+\$ 4000}$
$+$
Salary Expense
$-\$ 4000$

- Cash is credited, because it gives cashlets.

Salary Expense is debited, because it receives cashlets

\begin{tabular}{|c|l|l|l|}
\hline Date & Account & Amount & Notes \\
\hline Jan 30, 2017 & Cash & $+\$ 4000$ & \\
\hline Jan 30, 2017 & Salary Expense & $-\$ 4000$ & \\
\hline
\end{tabular}

On Jan 30, Laurens finds out that inventory is reduced by $\$ 2500$.

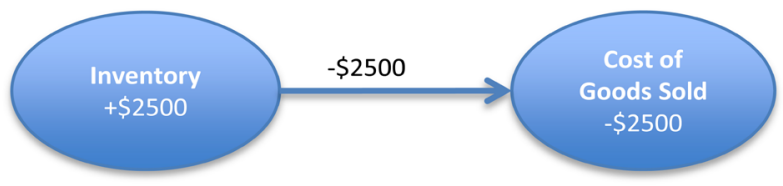

Business $=$ Assets + Liabilities + Common Stock + Revenue + Expense
$0=\frac{\text { Inventory }}{+\$ 2500}$
$+$
Cost of Goods Sold
$-\$ 2500$

— Inventory is credited, because it gives cashlets.

Cost of Goods Sold is debited, because it receives cashlets

\begin{tabular}{|l|l|l|l|}
\hline Date & Account & Amount & Notes \\
\hline Jan 30, 2017 & Inventory & $+\$ 2500$ & \\
\hline Jan 30, 2017 & Cost of Goods Sold & $-\$ 2500$ & \\
\hline
\end{tabular}

On Jan 31, Laurens pays the $\$ 1000$ to vendor for inventory purchased on Jan 5

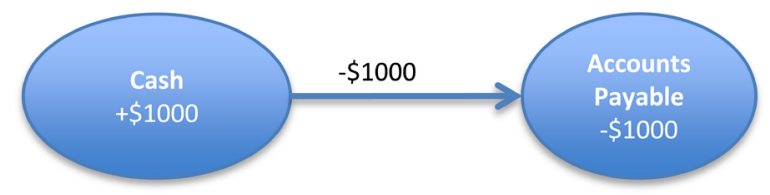

$$
\begin{aligned}
\text { Business } & =\text { Assets } \\
0 & =\frac{\text { Cash }}{-\$ 1000}+\frac{\text { Liabilities }+ \text { Common Stock + Revenue + Expense }}{+\$ 1000}
\end{aligned}
$$

- Cash account is credited, because it gives cashlets.

Accounts Payable is debited, because it receives cashlets

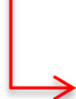

\begin{tabular}{|l|l|l|}
\hline Date & Account & Amoun \\
\hline Jan 31, 2017 & Cash & $+\$ 1000$ \\
\hline Jan 31, 2017 & Accounts Payable & $-\$ 1000$ \\
\hline
\end{tabular}


Event XIII On Jan 31, Laurens accrued \$50 interest expense for notes payable.

\section{Graphic \\ Analysis}

Equation

Analysis

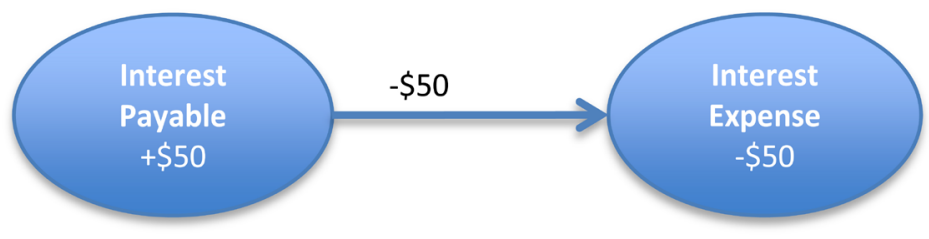

$$
\begin{aligned}
& \text { Business }=\text { Assets }+ \text { Liabilities }+ \text { Common Stock }+ \text { Revenue }+ \text { Expense } \\
& 0=\frac{\text { Interest Payable }}{+\$ 50}+ \\
& \text { Interest Expense }
\end{aligned}
$$

Debit-Credit Analysis

\section{Journal}

Entry

Interest Payable is credited, because it gives cashlets.
Interest Expense is debited, because it receives cashlets
\begin{tabular}{|l|l|l|l|}
\hline Date & Account & Amount & Notes \\
\hline Jan 30, 2017 & Interest Payable & $+\$ 50$ & \\
\hline Jan 30, 2017 & Interest Expense & $-\$ 50$ & \\
\hline
\end{tabular}

Figure 4. Illustration of graphic analysis, equation analysis, debit-credit analysis of transactions. Note that for journal entries, credit entry comes first then debit entry, which is different from traditional way, but more logical from the perspective of cashlet movements.

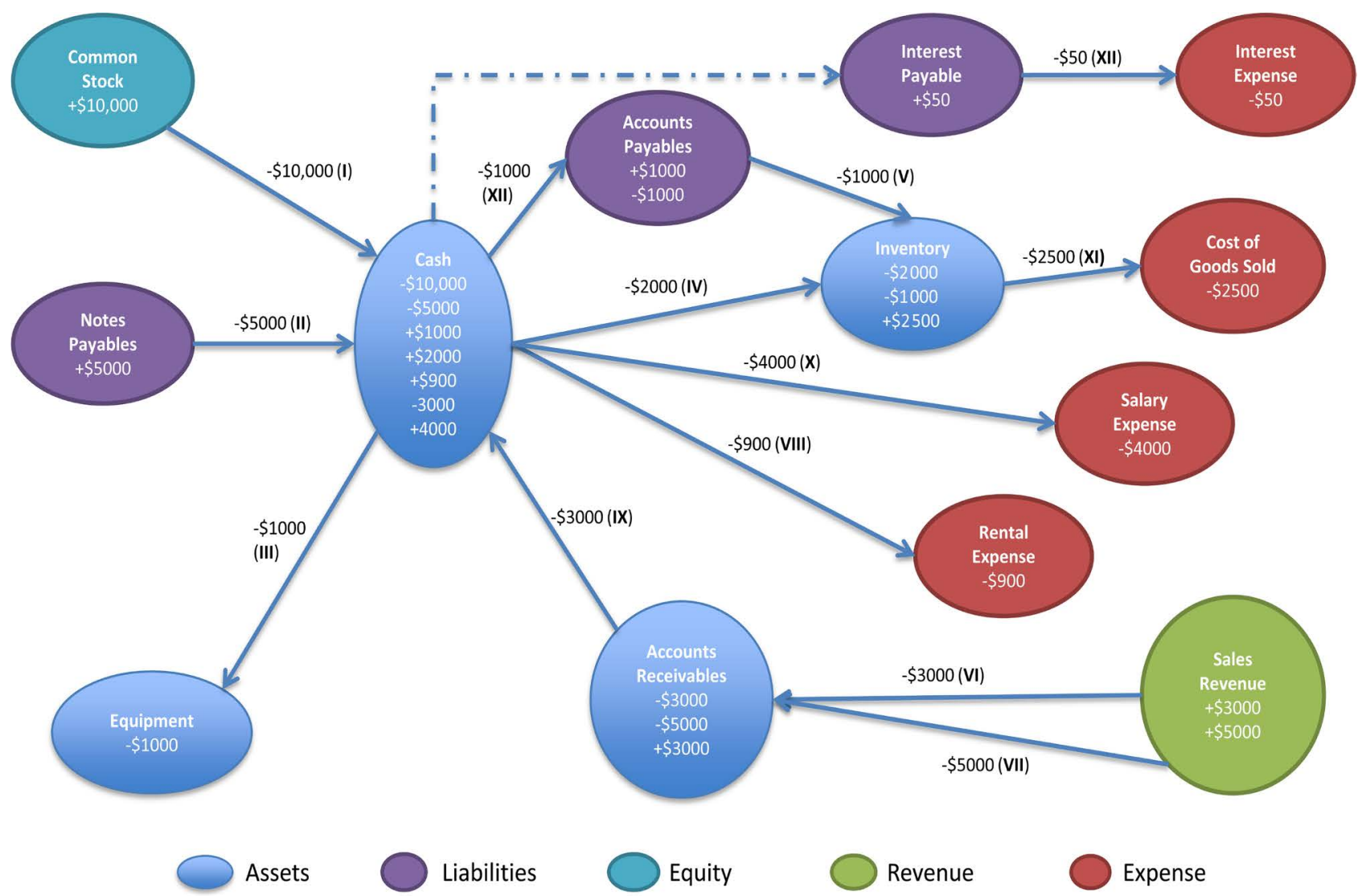

Figure 5. Illustration of all transaction in January 2017. Note that any accounts are connected directly or indirectly to cash account. The dash line denotes future transaction. 
Table 3. Journalized entries in a table. $(+)$ denotes credit balance while $(-)$ denotes debit balance.

\begin{tabular}{ccccc}
\hline Entry \# & Date & Account & Amount & Account Category \\
\hline 1 & $1 / 2 / 2017$ & Common Stock & $+\$ 10,000$ & Equity \\
1 & $1 / 2 / 2017$ & Cash & $-\$ 10,000$ & Assets \\
2 & $1 / 3 / 2017$ & Notes Payable & $+\$ 5000$ & Liabilities \\
2 & $1 / 3 / 2017$ & Cash & $-\$ 5000$ & Assets \\
3 & $1 / 4 / 2017$ & Cash & $+\$ 1000$ & Assets \\
3 & $1 / 4 / 2017$ & Equipment & $-\$ 1000$ & Assets \\
4 & $1 / 5 / 2017$ & Cash & $+\$ 2000$ & Assets \\
4 & $1 / 5 / 2017$ & Inventory & $-\$ 2000$ & Assets \\
5 & $1 / 5 / 2017$ & Accounts Payable & $+\$ 1000$ & Liabilities \\
5 & $1 / 5 / 2017$ & Inventory & $-\$ 1000$ & Assets \\
6 & $1 / 15 / 2017$ & Sales Revenue & $+\$ 3000$ & Revenue \\
6 & $1 / 15 / 2017$ & Accounts Receivable & $-\$ 3000$ & Assets \\
7 & $1 / 25 / 2017$ & Sales Revenue & $+\$ 5000$ & Revenue \\
7 & $1 / 25 / 2017$ & Accounts Receivable & $-\$ 5000$ & Assets \\
8 & $1 / 27 / 2017$ & Cash & $+\$ 900$ & Assets \\
8 & $1 / 27 / 2017$ & Rental Expense & $-\$ 900$ & Expense \\
9 & $1 / 30 / 2017$ & Accounts Receivable & $+\$ 3000$ & Assets \\
9 & $1 / 30 / 2017$ & Cash & $-\$ 3000$ & Assets \\
10 & $1 / 30 / 2017$ & Cash & $+\$ 4000$ & Assets \\
10 & $1 / 30 / 2017$ & Salary Expense & $-\$ 4000$ & Expense \\
11 & $1 / 30 / 2017$ & Inventory & $+\$ 2500$ & Assets \\
11 & $1 / 30 / 2017$ & Cost of Goods Sold & $-\$ 2500$ & Expense \\
12 & $1 / 31 / 2017$ & Cash & $+\$ 1000$ & Assets \\
12 & $1 / 31 / 2017$ & Accounts Payable & $-\$ 1000$ & Liabilities \\
13 & $1 / 31 / 2017$ & Interest Payable & $+\$ 50$ & Liabilities \\
13 & $1 / 31 / 2017$ & Interest Expense & $-\$ 50$ & Expense \\
\hline & & & &
\end{tabular}

Table 4. Balance by accounts. This table was calculated from Table 3 using Pivot Table (See Supplement).

\begin{tabular}{cr}
\hline Account & Balance \\
Cash & $-\$ 9100$ \\
Accounts Receivable & $-\$ 5000$ \\
Inventory & $-\$ 500$ \\
Equipment & $-\$ 1000$ \\
Accounts Payable & $\$ 0$ \\
Notes Payable & $+\$ 5000$ \\
Interest Payable & $+\$ 50$ \\
Common Stock & $+\$ 10,000$ \\
Sales Revenue & $+\$ 8000$ \\
Cost of Goods Sold & $-\$ 2500$ \\
Rental Expense & $-\$ 900$ \\
Salary Expense & $-\$ 4000$ \\
Interest Expense & $-\$ 50$ \\
\hline
\end{tabular}


Table 5. Balance by account categories. This table was also calculated from Table 3 using Pivot Table.

\begin{tabular}{cr}
\hline Account Category & Balance \\
\hline Assets & $-\$ 15,600$ \\
Liabilities & $+\$ 5050$ \\
Equity & $+\$ 10,000$ \\
Revenue & $+\$ 8000$ \\
Expense & $-\$ 7450$ \\
\hline
\end{tabular}

Table 6. Income statement.

\begin{tabular}{lcc}
\hline \multicolumn{1}{c}{$\begin{array}{c}\text { Laurens Corporation } \\
\text { Income Statement } \\
\text { For the month ended at January }\end{array}$} & \\
\hline $\begin{array}{l}\text { Revenue } \\
\text { Sales Revenue }\end{array}$ & $\underline{\$ 8000}$ & \\
Total Revenue & & $\$ 8000$ \\
Expense & $\$ 2500$ & \\
Cost of Goods Sold & 900 & \\
Rental Expense & 4000 & \\
Salary Expense & $\underline{\$ 50}$ & \\
Interest Expense & & $\$ 550$ \\
\multicolumn{1}{c}{ Total Expense } & & \\
Net Income & & \\
\hline
\end{tabular}

negative number (e.g. $-\$ 10,000)$ when it actually receives cash. This is because people do not differentiate cash from cashlet. Cash is real money, while cashlet is an accounting unit. In daily life, people use positive numbers to denote amount of cash, for examples "I owe you $\$ 10$ " or "I get $\$ 10$ ". However, cashlet is only used in accounting, and it is always negatively charged, which agrees the concept that "money is root of all evil (negative)". When stakeholders invest $\$ 10,000$ cash into a business, in real world the stakeholders give the real cash to the business owner. However in accounting, a Stakeholders' Equity account gives cashlets (not cash) to Cash account. Because cashlets are always negatively charged, the cash account gets a negative number whenever it receives cashlets. Remember any accounts can only give or receive cashlet(s) but not cash in accounting.

Most of accounting books use descriptive approach of natural language to present the double entry bookkeeping system, which works well for more than five centuries. But the approach requires significant human efforts to understand very basic concepts such as debit and credit, and it is not friendly to computers that operate with signed numbers illiterate of human concepts of debit or credit. Mathematicians have noted that abstract algebra can be used to study double entry bookkeeping system. Rambaud et al. (2010) wrote a book to introduce Al- 
Table 7. Balance sheet statement.

\begin{tabular}{|c|c|c|}
\hline \multicolumn{3}{|c|}{$\begin{array}{c}\text { Laurens Corporation } \\
\text { Balance Sheet } \\
\text { January 31, } 2017\end{array}$} \\
\hline \multicolumn{3}{|c|}{$\underline{\text { Assets }}$} \\
\hline \multicolumn{3}{|l|}{ Current Assets } \\
\hline Cash & $\$ 9100$ & \\
\hline Accounts Receivable & 5000 & \\
\hline Inventory & $\$ 500$ & \\
\hline Total Current Assets & & $\$ 14,600$ \\
\hline \multicolumn{3}{|l|}{ Property, plant, and equipment } \\
\hline Equipment & $\$ 1000$ & \\
\hline Total property, plant, and equipment & & $\$ 1000$ \\
\hline Total Assets & & $\$ 15,600$ \\
\hline \multicolumn{3}{|c|}{ Liabilities and Stakeholders' Equity } \\
\hline \multicolumn{3}{|l|}{ Current Liabilities } \\
\hline Accounts Payable & $\$ 0$ & \\
\hline Notes Payable & 5000 & \\
\hline Interest Payable & $\underline{\$ 50}$ & \\
\hline Total Current Liabilities & & $\$ 5050$ \\
\hline \multicolumn{3}{|l|}{ Stakeholders' Equity } \\
\hline Common Stock & $\$ 10,000$ & \\
\hline Retained Earning & $\$ 550$ & \\
\hline Total Stakeholders Equity & & $\$ 10,550$ \\
\hline Total Liabilities and Stakeholders' Equity & & $\$ 15,600$ \\
\hline
\end{tabular}

gebraic Models for Accounting [5]. Instead of defining the required double entry accounting rules using descriptive approach, the authors took an abstract algebraic approach by defining a number of axioms that are used to structure down the whole accounting system including transactions and balances [5]. The authors put a lot of theory into accounting, which makes the discipline rigorous rather than descriptive as it used to be. Lots of axioms and abstract algebra concepts-such as balance vector, digraph, monoid, homomorphism, quotient group structure and so on-are introduced to accounting, which is good for mathematicians to further study the accounting systems, but may not be beneficial for accountants who have little knowledge of abstract algebra. The book used "-" sign to denote Debit and "+" sign to denote Credit, which is the same with this study. But the reasons why these signs are introduced are from very different perspectives: one from mathematics and the other from chemistry. The authors also used graphs where accounts are vertices and edges are transactions, which is similar to this study. However, the concept of cashlet or its equivalence was not introduced. And the purposes of using graphs of the two studies are different: 
Rambaud et al. used graphs for mathematics purpose, while I use graphs to visualize the movement of cashlets between accounts. Kleppmann (2011) also introduced graph theory to accounting in his blog article "Accounting for Computer Scientists" [6]. However, without introducing the concept of cashlet, Kleppmann used cash or cash equivalence to denote the amount of each transaction. The relationships of graph and the concepts of debit/credit were not fully discussed in the article. In this work, cashlets and movements of cashlets are the key parts; graphs are used only for visualization purpose. However, these graphs are defined mathematically; they can be used for mathematics research in the future studies. It's possible that this study can be merged with studies of Algebraic Models for Accounting at some point.

The mathematics of double entry bookkeeping was well documented by Ellerman [7] [8] [9] [10]. According to his classification, the mathematical treatment I use in this study belongs to single sided system (SSS) with signed numbers. In Ellerman's article, the asset accounts are with positive numbers while liability and equity accounts are with negative numbers [10]. In this study, Iuse the opposite treatment: asset accounts are with negative numbers while liability and equity accounts are with positive numbers. Both treatments are good from mathematics' point of view. However, the method I use in this study make more sense in the context of cashlets and cashlet movements between accounts from the view of chemistry.

Chemists may notice that the credit state in this study is not exactly the same with the concept of oxidization state in chemistry. The purpose of introducing credit state is to facilitate the understanding of accounting transactions, but not to create an exactly the same concept of oxidization state in accounting. For accountants, they do not need to know how credit state was derived unless they really want to. In cashlet theory, credit state is the cashletic charge of an account, which is also different from chemistry.

In this study, I avoid the discussion of the cash flow statement, because the purpose of this article is to introduce novel concepts to accounting enlightened by chemistry. It will be very interesting to study cash flow using these novel concepts in the future. It will also be interesting to study the cashlet flow and to visualize how cashlets moves from accounts to accounts. From the preliminary study, I have noticed that any accounts should be connected to cash account directly or indirectly at some point of time in the graph. Cash account serves as a hub for all accounts. It will be very interesting to study how cashlets move from cash account to other accounts and how they come back from other accounts to cash account.

Cashlet theory will potentially make accounting easier in practice especially for the current digitalized world where everything is recorded as computerized data. Computers themselves do not understand human concepts like debit or credit. However computers are extremely good at dealing with signed numbers. In practice of accounting related enterprise applications, the application designers usually specify the negative sign to debit or credit balance/post for a default 
setting. For example, the default setting of SAP ERP (Enterprise Resources Planning) is that debit balance is with a negative sign [11]. The practice of using signed number to represent debit or credit has existed for decades in computer science. However, the accounting world still prefers the descriptive approach that were invented more than five centuries ago. This increases the work for computer scientists to translate computerized accounting languages to that of accounting world. The gap between accountants and computer scientists is due to the lack of a widely accepted theory for both sides to adopt signed number system of accounting. Due to this absence, the usage of positive or negative sign in accounting applications is not standardized, and it depends on the application designers. For example, SAP ERP allows users to set negative sign to debit balance or credit balance during the implementation [11]. This non-standardization of sign usage in accounting applications in turn causes confusing for accountants. By introducing cashlet, cashlet movement and graph theory, the cashlet theory provides full theoretical support for current practices of using signed numbers in accounting software. This theory is also easy for people including both accountants and computer scientists to understand. If it is widely accepted, the sign usage can be standardized, which will cause less confusing for all people. The graphs used in this theory may be helpful for accounting application development, because graph theory is a sound theory to be implemented in software development.

Cashlet theory can not only be applied to monetary accounting, but also to non-monetary accounting. With the emerging of new technologies and new forms of economic activities, this theory will be very useful. For example, the new economic form of Time Banking-the exchange of services using timebased currency-is not of a monetary system [12]. Using cashlet theory, the accounting for this new economic form become easier. The entity that provides services should be credited, while the one who receives services should be debited. Each of the transactions move cashlets from provider to receiver for cashletic accounting's point of view. In a broader sense, cashlet theory can be applied to any type of economic transactions that are quantifiable, not limiting to monetary transactions, which may be very helpful in economic research as well.

\section{Conclusion}

This article proposes a scientific theory for accounting: It first introduces a novel concept of cashlet-a basic accounting unit with negative charge-that is equivalent to electron in chemistry. It then deduces that an accounting transaction is a process of moving cashlets from one account to another, and that the total cashletic charges of all involved accounts should remain unchanged before and after transactions. The account that gives cashlets is credited, while the account that takes cashlets is debited. In this theory, credit always means positive or plus (+), while debit always means negative or minus $(-)$. The article concludes that the nature of accounting is a process of moving cashlets between accounts which is known as debit-credit transactions, and a process of recombining accounts 
which are known as reconciliation in accounting. This article also helps people better understand the world in that accounting transactions and chemical reactions are the same in nature, and in that when you give you get credits when you take you get debits.

\section{References}

[1] Galassi, G. (1996) Pacioli, Luca. In: Chatfield, M. and Vangermeersch, R., Eds., History of Accounting. An International Encyclopedia, Garland Science, New York, c1445-c1517.

[2] Kimmel, P.D., Weygandt, J.J. and Kieso, D.E. (2012) Financial Accounting: Tools for Business Decision Making. 7th Edition, Wiley, Hoboken.

[3] Boyer, R. (2016) Concepts in Biochemistry-Concept Reviews. http://www.wiley.com/college/boyer/0470003790/reviews/redox/redox.htm

[4] Deo, N. (2016) Graph Theory with Applications to Engineering and Computer Science. Dover Publications, Mineola.

[5] Rambaud, S.C., Pérez, J.G., Nehmer, R.A. and Robinson, D.J.S. (2010) Algebraic Models for Accounting Systems. World Scientific Publishing Company, Hackensack. https://doi.org/10.1142/7445

[6] Kleppmann, M. (2011) Accounting for Computer Scientists. https://martin.kleppmann.com/2011/03/07/accounting-for-computer-scientists.html

[7] Ellerman, D.P. (1982) Economics, Accounting, and Property Theory. Lexington Books, Lexington.

[8] Ellerman, D.P. (1985) The Mathematics of Double Entry Bookkeeping. Mathematics Magazine, 58, 226-233. https://doi.org/10.2307/2689520

[9] Ellerman, D.P. (1986) Double Entry Multidimensional Accounting. Omega, 14, 13 22.

[10] Ellerman, D.P. (2014) On Double-Entry Bookkeeping: The Mathematical Treatment. Accounting Education, 23, 483-501. https://doi.org/10.1080/09639284.2014.949803

[11] https://help.sap.com/saphelp_sbo882/helpdata/en/45/07edb6ae742461e10000000a1 553f7/content.htm

[12] Smith, A. (2016) Time-Based Money of Our Times. http://www.huffingtonpost.com/allan-smith/timebased-money-of-our-ti_b_132752 76.html 
Submit or recommend next manuscript to SCIRP and we will provide best service for you:

Accepting pre-submission inquiries through Email, Facebook, LinkedIn, Twitter, etc. A wide selection of journals (inclusive of 9 subjects, more than 200 journals)

Providing 24-hour high-quality service

User-friendly online submission system

Fair and swift peer-review system

Efficient typesetting and proofreading procedure

Display of the result of downloads and visits, as well as the number of cited articles Maximum dissemination of your research work

Submit your manuscript at: http://papersubmission.scirp.org/

Or contact ojacct@scirp.org 